\title{
Research on the Teaching System of the University Computer Foundation
}

\author{
Xiaoyun $\mathrm{Ji}^{1, \mathrm{a}}$, Bin $\mathrm{Hu}^{2}$ \\ ${ }^{1}$ Department of College Fundation Education, Bohai University, Jinzhou, China \\ ${ }^{2}$ College of information science and technology, Bohai University, Jinzhou, China
}

\begin{abstract}
Inonal students, the teaching contents, classification, hierarchical teaching methods with the combination of professional level training, as well as for top-notch students after class to promote comprehensive training methods for different students, establish online Q \&amp; A, test platform, to strengthen the integration professional education and computer education and training system of college computer basic course of study and exploration, and the popularization and application of the basic programming course, promote the cultivation of university students in the computer foundation, thinking methods and innovative practice ability, achieve the goal of individualized educ the College of computer basic course teaching, the specific circumstances of the need for students, professiation.
\end{abstract}

\section{Introduction}

May 23, 2015, the Ministry of education of Liberal Arts Computer Teaching and guidance of the committee, "computer based curriculum teaching requirements," the revised work conference held in Renmin University of China. The basic orientation of computer based course "application" is defined, and the basic principle of knowledge learning is to cultivate students "ability to solve problems. It is also the ability of each knowledge unit to solve the problem.

In recent years, the university computer based student training and classroom teaching results, since 2009 , the process control management, the teaching effect has been improved, but the students' basic level difference is still relatively large, students are generally not very high acceptance of computer courses. This thesis mainly focuses on these differences, how to carry out in-depth research on the teaching system of College Students' computer basis.

\section{The goal of the computer based teaching system}

First, the construction of basic computer course in university students graded exemption, teaching content classification, hierarchical teaching, assessment and evaluation system;

Second, basic computer courses in University of students grading system and grading assessment methods, the contents of the evaluation and examination paper definition, reflecting students' ability in computer based classification of discrimination, to master the basic knowledge of the students implement exempt and exempt from computer basic course in the subsequent content learning and management;

Third, the study of different professional disciplines and the university computer based curriculum content, the formation of large and small professional computer based curriculum needs analysis, and for different disciplines to design teaching content and assessment methods, to achieve the combination and optimization of teaching content;

Fourth, according to the development of computer system, the new system, such as Office2010 and Windows7, to revise the teaching material, the subject needs as the core, to establish a new teaching material system;

Fifth, the establishment of the computer application of teaching content as the main body of the teaching program, to make up for the lack of classroom theory teaching;

Sixth, the establishment of scientific and technological innovation, competition platform, through the pre competition training and guidance, to strengthen the students after class learning. Greatly improve the quality of computer application, to encourage students to choose a higher degree of difficulty of the practice of topics, stimulate the students' potential, improve their analytical problems, solve the problem of ability and ability to do.

${ }^{\mathrm{a} C o r r e s p o n d i n g ~ a u t h o r: ~ b h d x j x y @ 126 . c o m ~}$

Project number: 2014-A101, project name: the research and practice of the teaching system of computer basic level in University 


\section{The specific content of the research on the computer based hierarchical teaching system}

\subsection{Research on the classification scheme of teaching object and its discrimination}

For first-year undergraduate computer basic teaching object classification, the grading assessment methods, appraisal content and the appraisal of discrimination, through investigations, classification of good, common and poor foundation of students, distribution, research exemption system and exempt from students of computer basic teaching contents, methods, evaluation system; study different subjects of students grading assessment methods, and gradually form a perfect classification exemption system.

\subsection{Research on the content level of computer basic teaching in University}

According to the basic theory of software, the computer and the computer should be used to improve students' level of learning interest. According to the basic theory of computer science, such as the teaching content of computer, the research of the teaching method, the teaching method, the teaching method of computer science, the teaching method of the computer, the teaching method of the teaching, the teaching method of the computer, the teaching method, the teaching method of the computer, the teaching method of the teaching, the students' understanding of the teaching method. Knowledge of classroom teaching, autonomous learning, and after class reading.

\subsection{Research on the teaching method of the integration of computer related technology and computer basic course in subject}

The college or university of professional units, the scope of application of computer technology in the research of professional requirements, typical technology, for the students' basic knowledge of computer requirements, construction of new courses teaching case library, adjust and modify the courseware; for the professional course design work, Office show the computer technology in the application of professional in the competitions and other activities, improve the students' interest; division of teachers for professional, full-time teachers to set majors different, through continuous 2-3 years of teaching practice, deepen students' demand for professional categories and the subsequent development of tracking, and gradually improve the integration of students professional and related computer technology, training the classification system of computer basic course level form.

\subsection{The competition of talent cultivation and innovation of science and technology "after class" plan}

Long-term mechanism to establish the school program design contest or off campus program design competition, to create a once a year, the students are extremely attractive and brand school program design competition; establish mechanisms for training and competition in personnel, school science and technology innovation of training plan and training programs; organization of top-notch students to participate in some influential national and international competition and enhance students' innovation ability and practice ability, and strive to can get the first prize in the national competition within a few years.

\section{Methods and measures for the study of the hierarchical teaching system}

The basic computer proficiency test method, test for undergraduate computer basic level, the implementation of a, B, C classification and setting the exemption system, for a class of students can exemption experiment course or courses, some advanced experimental courses and theory courses elective curriculum.

Establish large specialty group, with arts, science, engineering category of coarse packet, different disciplines for basic computer courses teaching requirements, forming division of teaching knowledge points; according to the common features of the school curriculum, construction of basic courses module, namely software foundation, basic hardware, office based analysis, in different disciplines, organization optimization operating system, multimedia, computer network and advanced application experiments of different modules and the degree of difficulty, forming different disciplines teaching plan. See Table 1.

Table 1. Computer basic course requirements for each subject

\begin{tabular}{|c|c|}
\hline Subject & Course requirements \\
\hline Liberal arts & $\begin{array}{c}\text { Common office } \\
\text { softwar }\end{array}$ \\
\hline science & Office software, \\
\hline $\begin{array}{c}\text { drawing, the use of } \\
\text { specialized software }\end{array}$ \\
\hline engineering & $\begin{array}{c}\text { Office software, the } \\
\text { use of a variety of } \\
\text { tools }\end{array}$ \\
\hline
\end{tabular}


According to different professional organization of teachers establish the appropriate team continued the same professional teaching; teachers' organizational and professional teachers to communicate and study of computer basic courses and between different professional knowledge structure; organization teachers are professional relevant case base design, and carries on the analysis to the case, and gradually improve the courseware, forming large specialty knowledge structure graph.

Revision of teaching materials, according to the Windows7 and Office2010, design the content of experimental practice courses, according to the current network technology, mobile communications, multimedia and other technology to supplement textbooks.

Relying on the campus network platform, the establishment of students before class computer foundation for investigating the mechanism, design questionnaire, let each teacher master the class the students basic level, appropriate adjustments to the teaching schedule; the establishment of student feedback system, through the automatic evaluation platform of background data analysis students to grasp the weak link; open self-test questions, online answering system and knowledge evaluation system, the students through self assessment knowledge master and teacher's teaching situation, taking the opportunity of feedback to improve the teachers explain focus.

Reform of examination system, based on the study of computer operation and computer theory, combined with the formation of small papers, job development, advanced computer applications, such as a comprehensive assessment system.

Organize relevant teachers to participate in the National University computer foundation curriculum, training, and establish a school visit and inspection mechanism, and other college computer based courses teaching team to communicate, learn advanced teaching methods, exchange courseware material; through the system to discuss the typical teaching methods, for the current courseware.

Optimize the subject and content of the lecture plan, to create a continuous series of lectures for students interested in computer application, to add the students' understanding of the latest technology, improve learning interest.

The establishment of computer technology in the professional application of the small papers, continue to promote the Office job fair, try to use computer advanced application of the practice, improve students learning motivation.

Create a year of a brand, the school computer programming contest, to arouse students' interest in learning; organization of top-notch students to participate in some influential national and international competition and enhance students' innovation ability and practice ability; create competition platform, improve students' after-school training contents and related materials, according to the different organization of the competitions of the regular classroom training, promote the innovation ability of the students in the application of computer technology.

\section{The teaching method of the hierarchical teaching system}

In accordance with the requirements of the reform of the teaching model, the implementation of "rotation classroom mode to teaching target as guidance, combining the traditional teaching method and modern teaching means, use inspire, inquiry, discussion, case and competition so as to teaching methods, guide students to move the brain, hands, realize the teacher-student interaction, students interaction, stimulate students learning interest and enthusiasm in learning, improve the quality of teaching.

\subsection{Class Preview}

Teacher at least three days ahead of schedule to the students preview content. To establish the QQ group, used to assist the exchange of information between teachers and students, including the preparation of the task of publishing. At the same time, the establishment about study group (5-6), by small group leader is responsible for the preview, seminars, open research, homework collection work group member class, helping the teacher to complete the teaching of the classroom after class.

\subsection{Discuss the test before class}

Use before class 10-20 minutes time to test preview task completion, guide the students to master the basic knowledge of learning this lesson, and according to the test to determine the grades of students reading. Inspection methods can be flexibly used according to different contents.

\subsection{Class teacher essence}

Teachers according to the students to preview task completion, to explain the knowledge induction and focuses on the problem of presentation by 50 to 60 minutes at a time, in the middle can be interspersed combination of lecture and practice, or let the speaker student, the formation of the interaction between teachers and students.

\subsection{Practical training after class}

Use 10-20 minutes after class to focus on the course of the training of key knowledge, through the answer questions, solve the problem of the way to consolidate 
the focus of knowledge, cultivate the ability to solve practical problems.

\subsection{Under class guidance}

Teachers in the arrangement of the class of students to complete the task after the task, according to the requirements of students personalized counseling, discussion, answering questions to help students complete the task of learning, while the layout of the new curriculum preview task.

\section{Summary}

In college computer basic courses of University of hierarchical teaching, and Ministry of Education Computer Teaching Steering Committee to develop the college computer teaching requirements "coincide. The guiding ideology, the main problems and challenges of the computer foundation course, the teaching objectives and contents of the course, the emphasis and difficulty of the revision work, the task division of labor and the time schedule, etc.
In the process of writing, Thanks for the Department of leadership and colleagues, as well as the school's strong support!

\section{References}

1. Zhenting Li," Visual Basic Programing Course", Northern Jiaotong University press, January2003 (In Chinese)

2. Yongquan Lu, "Use of VB development environment of multimedia software", Chinese computer newspaper,Vol 22,June 1997 (In Chinese).

3. HaiZhen Wu,JiaFu Jiang, "VB language teaching reform of Oriented programming ability cultivation", J. Journal of Educational Science of Hunan University, vol 4(6), pp. 120-122, July 2005 (In Chinese)

4. K. Elissa, "Title of paper if known," unpublished.

5. Zhiwei Li, "The realization of Oracle Database's Backup Sync in VB Environment", Computer Engineering and Design, July 2009 